\title{
Notatniki zamiast opus magnum?
}

Krystyna Pietrych 


\section{Notatniki zamiast opus magnum?}

Krystyna Pietrych

TEKSTY DRUGIE 2017, NR 4, S. 115-130

DOI: $10.18318 /$ td.2017.4.7

$\mathbf{W}$ iększość książek Aleksandra Wata ma status szczególny - autor nigdy ich nie ukończył ani tym bardziej nie zdecydował się na ich publikację, skazując tym samym na nieistnienie zarówno Mój wiek, części szkiców ze Świata na haku i pod kluczem, jak i Dziennik bez samogtosek, by wymienić teksty dla tej twórczości fundamentalne, bez których trudno dziś sobie wyobrazić polską XX-wieczną diarystykę czy eseistykę. Przed śmiercią Wat pisał dobitnie i jednoznacznie: „Wszystkie papiery nie do wykorzystania, albo notatki czy stenogramy, którym dopiero w opracowaniu nadałbym formę, oryginalność czy siłę”. Bądź w innym miejscu: „Nie dać ludziom grzebać się w papierach, najlepiej spalić"2.

Decyzję o druku tych skazanych na zagładę papierów, mimo zasadniczych wątpliwości, podjęła za namową przyjaciół żona pisarza, Ola Watowa, ocalając w ten

1 A. Wat Notatniki, transkrypcja i opracowanie A. Dziadek, J. Zieliński, Wydawnictwo IBL PAN, Warszawa 2015, s. 842.

2 Tamże, s. 871.

\section{Krystyna Pietrych}

- dr hab. prof. UŁ.

Autorka książek "Co

poezji po bólu?"Em-

patyczne przestrzenie

(2009), O,Wierszach

śródziemnomorskich"

Aleksandra Wata,

1996) oraz edytorka

(wraz z Piotrem

Pietrychem) pism

Wata (Dziennik bez

samogłosek; 2001).

Główny obszar jej za-

interesowań stanowi

XX-wieczna poezja

polska. Redaktor

naczelna rocznika

„Czytanie Literatu-

ry. Łódzkie Studia

Literaturoznawcze".

Kierownik Interdyscy-

plinarnego Centrum

Badań Humanistycz-

nych UŁ. Kontakt:

pietrych@op.pl 
sposób spuściznę autora Ciemnego świecidła ${ }^{3}$.Że była to decyzja ze wszech miar słuszna, trudno mieć dziś jakiekolwiek wątpliwości. Jednak w efekcie kształt publikowanych książek to w znacznym stopniu efekt jej wysiłków i pracy kolejnych edytorów pism Wata.

Warto mieć tę świadomość, sięgając po jego Notatniki, w transkrypcji i opracowaniu Adama Dziadka i Jana Zielińskiego, ponieważ w jakiejś mierze kontynuują one tę szczególną tradycję wydawania kolejnych dzieł Wata - dzieł o kształcie jedynie hipotetycznym, zawsze nieostatecznym, bo nieposiadającym autorskiego imprimatur. Z drugiej jednak strony Notatniki zajmują w tym szeregu pozycję osobną; są rodzajem złożonych, wielowarstwowych, niegdyś byśmy powiedzieli, brudnopisów, nad którymi Wat pracował bądź które planował; brudnopisów, które wobec braku czystopisu, nabierają szczególnego znaczenia - tylko w kilku miejscach stanowią przed-teksty utworów opublikowanych za życia pisarza, w przeważającej zaś części zyskują charakter samodzielny, nie tyle jednak w sensie kompletnej i domkniętej struktury tekstu, co podlegającego wewnętrznym przemianom, zawsze niedokończonego, dynamicznego toku pisania. To przede wszystkim wyrazisty i wielowymiarowy ślad procesu twórczego, unaoczniający jego zmienność, pokazujący liczne zerwania i kontynuacje, leitmotivy i obsesyjnie powracające tematy. Taki sposób widzenia tekstu zgodny jest ze stanowiskiem krytyki genetycznej, w przestrzeni której edytorzy Notatników sytuują omawiane wydanie.

Co odkrywa przed nami lektura Notatników Wata? Co nowego pozwala dostrzec? Jak zmienia (jeśli zmienia) obraz tej twórczości? Co wnosi do wizerunku autora, kreowanego również przez niego samego? I - jakie cele realizuje edycja Notatników w takim kształcie?

W Przedmowie do Mojego wieku, która zaprojektowała na długie lata niemal kanoniczny sposób lektury całej twórczości Wata, Miłosz pisał:

wiersze Aleksandra pochodzą z nadmiaru i [...] są drobną częścią wielkiej całości, która bez ustanku w nim się układa, domaga się głosu i której inną częścią są urzekające słuchaczy opowieści świadka i uczestnika wydarzeń. Sednem tej całości, do napisania, miało być filozoficzne objaśnienie istoty zjawiska, które dla Wata streszczało wszystkie zwyrodnienia dwudziestego wieku - tj. sowieckiego komunizmu. Wat czuł się obarczony moralnym obowiązkiem wobec nieszczęść milionów ludzi, jakiejkolwiek

3 Zob. wstęp Pauliny (Oli) Watowej do A. Wat Świata na haku i pod kluczem. Eseje, oprac. K. Rutkowski, Czytelnik, Warszawa 1991, s. 5-6. 
narodowości, tego nieszczęścia, z którym zetknął się w kolejnych więzieniach. [...] Wat pochodnymi zjawiska, np. w „demokracjach ludowych”, nie miał zamiaru bliżej się zajmować, jego obchodziło "skąd i dlaczego" systemu, jaki powstał w Rosji. ${ }^{4}$

Miłosz stawiał także istotne pytanie o przyczyny niemożności zrealizowania owej całości i celnie na nie odpowiadał:

Czy, gdyby nie ciężkie nawroty choroby, Wat napisałby swoje wielkie dzieło-całość? Można podejrzewać, że nie tylko choroba, tj. uniemożliwiające jakąkolwiek robotę bóle w połowie twarzy, często w całej twarzy i w głowie, stanowiła przeszkodę, ale właśnie nadmiar treści [...]. Jak słusznie powie Konstanty Jeleński, zadowolić Wata mógł tylko „taniec kosmiczny, dzieło pt. „Wszystko o wszystkim”, ogarniające politykę, ale także daleko poza nią wykraczające. Bo Wat nie zamierzał być kronikarzem swojego wieku, szukał w wydarzeniach ich treści sekretnej, ukrytej. Kształt nadany myśli Marksa w Rosji był dla niego dotykalnym objawem wyroków do odcyfrowania, plag ściągniętych na siebie przez całą ludzkość. ${ }^{5}$

Tropy wskazane przed laty przez Jeleńskiego i Miłosza w kontekście wydania Notatników Wata zyskują potwierdzenie i głębokie uzasadnienie. Podczas ich lektury uderza przede wszystkim wielowymiarowa totalność projektu Wata, to, co Miłosz nazwał „nadmiarem”, a Jeleński próbą „odtworzenia borgesowskiej Biblioteki"6. Notatki Wata przynoszą niesamowitą liczbę w różnym stopniu zrealizowanych tekstów - planowanych, rozpoczętych, zaniechanych, porzuconych, ale także domkniętych i ukończonych. Stanowią także świadectwo rozległych i wielokierunkowych zamysłów pisarskich Wata - całe stronice wypełniają listy lektur, wypisy z kolejnych studiowanych książek, początki i ciągi dalsze następujących po sobie (a może powstających równolegle) twórczych przedsięwzięć, częste powroty do tego, co niegdyś było rozpoczęte, potem zarzucane, by ponownie w inny sposób zostać podjęte.

4 Cz. Miłosz Przedmowa, w: A. Wat Mój wiek, rozmowy prowadził i przedmową opatrzył Cz. Miłosz, do druku przygotowała L. Ciołkoszowa, Czytelnik, Warszawa 1998, t. 1, s. 11.

5 Tamże, s. 11-12.

6 K. Jeleński Lumen obscurum, „Wiadomości”, Londyn, 10 XI 1968 (jest to recenzja tomu Wata Ciemne świecidło). 
Fascynująca i zarazem porażająca jest ta gigantyczna, splątana wielość, tworząca hybrydyczny tekstowy świat, który w przeważającym stopniu na zawsze pozostaje w stanie nieukończenia i potencjalności, w fazie permanentnych narodzin. Edytorzy używają dla oddania tej heterogenicznej wielości metafory „spiralnej nielinearności zapisu” i kategorii kłącza. Oczywiście w jakiejś mierze zbiór rękopiśmiennych notatek każdego pisarza nie jest linearny i realizuje typ zapisu rozgałęziającego się w wielu kierunkach naraz. W tym przypadku jednak mamy do czynienia z tym zjawiskiem w stopniu ekstremalnym i - co jeszcze ważniejsze - dającym się potraktować jako specyficzna właściwość, swoista sygnatura całego pisarstwa Wata, ujawniająca się w ciągłym nawrocie tych samych tematów, motywów, idei i pomysłów, które pojawiają się zarówno w jego prozie, jak i poezji. Te nieustanne powtórzenia w opublikowanych notatnikach są jeszcze intensywniejsze, bardziej gorączkowe i dramatyczne. Fakt, że nie zaistnieje nigdy „ostateczna perfekcyjność dzieła" ', że nie uzyskamy tekstowego domknięcia, finalnego rezultatu, zyskuje znaczenie szczególne - wyraża przeświadczenie o niewyrażalności kwestii najważniejszych. W Notatniku I czytamy:

... wyrażamy tylko część wszystko co / tylko część wszystkiego co / widzimy i słyszymy, wszystko / czego doznajemy, co odczuwamy/ i przeżywamy, resztę - czasem / niekiedy większą, niż tamta - / pozostawiając na łaskę / bezsłownej, niewymownej wiedzy /samowiedzy wewnętrznej, która / nie będąc zafiksowana w słowach, / nie mając konkretnej postaci / może ulegać wszelkim zniekształceniom / i może się rozpełznąć w niepamięci. ${ }^{8}$

A w zeszycie ostatnim znajdujemy następujące wyznanie:

zawsze nie lubiłem drukować publikować. Nie cierpiałem. / Zbierało mi się i zbiera na wymioty, gdy widzę swoje utwory wydruko-/ wane czarno na białym: ten hiatus między wizją a jej / realizacją, między zamierzeniem i wiedzą tajemną i / produktem pracy zawsze od początku przerażał mnie. Była to zawsze / dla mnie repetycja upadku i deprawacji aniołów, niezależnie / od tego, czy mnie wykpiwano, czy chwalono (bo i to bywało). / Pisałem wiele, ale drukowałem wyłącznie pod wpływem chwilowych

7 P.-M. de Biasi Genetyka tekstów, przekład F. Kwiatek, M. Prussak, Wydawnictwo IBL PAN, Warszawa 2016, s. 15.

8 A. Wat Notatniki, s. 34. 
impulsów, irracjonalnych, / albo gdy mnie wyciąg redaktorzy do tego przymuszali, albo z / pobudek interesownych [... $]^{9}$

Przytoczone fragmenty wydobywają ścisły związek między maksymalistycznym dążeniem do "wyrażenia wszystkiego" i poczuciem, że „większa część wszystkiego" sytuuje się poza słowem a niechęcią do publikowania własnych tekstów, wynikającą z paraliżującej świadomości istnienia przepaści między zamysłem („wiedzą tajemną”) i realizacją („upadkiem”). Dziwnym zrządzeniem losu (bo raczej nie przypadkiem) powyższe wypowiedzi utworzyły swoistą klamrę notatników Wata. Dziwnie symptomatycznym, można dodać, bowiem wydobywają one konstytutywną cechę specyfiki twórczej autora Ucieczki Lotha - niemożność zaakceptowania ostatecznej formy wypowiedzi, takiego jej kształtu, który na zawsze pozostałby niezmienny. Wat domaga się od tekstu rzeczy niemożliwej - dokonywania nieustannych zmian, wprowadzania przekształceń i dopowiedzeń; stałego otwarcia na to, co się pojawia już po zakończeniu pisania; niewykluczania kontrznaczeń i nurtu treści pobocznych, utajonych, jedynie przeczuwanych, pozostających poza tokiem uporzą dkowanego dyskursu. Dlatego tak często bieg jego myśli jest logoreiczno-meandryczny, dygresyjny (sam go często nazywał rapsodycznym), rozsadza sekwencję nie tylko linearną, ale poprzez asocjacyjność, także przyczynowo-skutkową. Widać to świetnie już choćby we wcześniejszej publicystyce, ale w sposób spotęgowany i wręcz modelowy tę ciągłą zwłokę, ucieczkę od definitywnego końca, odnajdywanie słów i ich porzucanie, kluczenie od jednej formy do innej, niekończące się zmaganie z kolejnymi pomysłami możemy śledzić w Notatnikach, które pokazują proces pisania jako spotęgowanej wariantywności, pochwycony in statu nascendi - w ciągłej niegotowości i nieostateczności. Wewnętrzna, odśrodkowa siła, erupcja myśli i skojarzeń rozsadza tu zawsze to, co choćby przez chwilę może sprawiać wrażenie działania teleologicznie ukierunkowanego, znajdującego swój finał w literackim spełnieniu.

Coś jednak poza wyrazistą podmiotowością uspójnia wszystkie rękopiśmienne zapisy - to stale od nowa podejmowany przez Wata wysiłek zmierzenia się z tematem dla niego najważniejszym: komunizmem. Przy czym chodzi mu o wpisywanie komunizmu w jak najszerszy plan dziejowy, i jednoczesne wskazanie $\mathrm{i}$ analizę tego, co w systemach totalitarnych wszystkich czasów trwałe i niezmienne. Zapisy w Notatnikach potwierdzają po raz 
kolejny to, co wynikało wcześniej z lektury Dziennika bez samogłosek, Mojego wieku, licznych szkiców czy korespondencji - to zatem, że Wat długie lata planował napisanie dzieła totalnego, w którym miała się pomieścić osobista refleksja dotycząca własnej biografii uwikłanej w XX-wieczną historię ściśle połączona z rozpoznaniem uniwersalnych mechanizmów historii, nie tylko w jej współczesnej, komunistycznej odmianie, ale zmierzającym do ogólnej diagnozy prawidłowości historiozoficznych. Ten nierealizowalny zamysł co i rusz pojawia się w jego brulionach - a to przez przywołanie historii kalifa z XVII wieku, wskazywanie podobieństw między despotyzmem Iwana Groźnego a stalinizmem bądź innym razem poprzez odwołania do dziejów starożytnego Egiptu, rewolucji francuskiej czy najazdów Dżingis-chana. Można te fragmenty zobaczyć jako projekty kolejnych rozdziałów Watowskiego Lebenswerku, dzieła, które nigdy nie powstało, bo powstać nie mogło, ale było zamysłem, któremu Wat pozostał wierny i który ścigał przez całe życie. Był zresztą świadom utopijności własnego projektu - w 1964 roku notował:

A tu idzie o liście z drzewa spadające, a więc z drzewa jesiennego. Unoszone przez wiatr bezładnie. Boi mnie na nic innego nie stać było, nigdy, a zawsze chciałem pisać tylko Czerwone i czarne lub Krytykę praktycznego rozumu. To się zemściło. [...]

Więc rzeczywiście, najlepiej dla mnie, [...] zrobić nie Dziennik [...], ale zbiór kartek. [...] Wpakować tam, oszlifowawszy, uwolniwszy od gadulstwa, wszystko co wartościowe albo co można uwartościowić z tych doprowadzających mnie do rozpaczy, niechlujnych papierzysk, wszystko o ludziach, o polityce, o Stalinie, o poezji, o San Francisco, o Cabris, o sobie, o naszej rodzinie, obrazki z Rosji, z więzień, fakty, rozmyślania, zapisy rozmów, portrety miast, ludzi, czasu, kontynentów, noty czytelnika gazet, nawet wiersze i obszerne komentarze do nich, wspomnienia o przyjaciołach, obserwacje, ideologie itd., itd. Zasadą: wszystko, co ma wyraz i czemu potrafię nadać kształt. ${ }^{10}$

Ta autodiagnoza nie do końca, na szczęście, okazała się prawdziwa. Nie powstała, co prawda, książka przez duże „K”, Watowskie Czerwone i czarne, ale powstały inne utwory (we fragmentach pośmiertnie opublikowane), przede wszystkim - poetyckie. Wraz z realizowanymi i planowanymi tekstami 
mnożyły się notatki, świadectwo zmagań pisarza z własnymi pomysłami, planami, niemożnościami, zwątpieniami. Bez względu na to, jaką przybierały formę, ich zasadniczym tematem pozostawał nieodmiennie komunizm - nieustannie powraca w nich nazwisko Stalina w różnych kontekstach i uwikłaniach. Trudno zgodzić się z Janem Zielińskim, który pisze:

Gdyby szukać wspólnego mianownika poruszanych w notatnikach zagadnień - zadanie karkołomne wobec rozpiętości erudycji i zainteresowań Wata - taką nicią przewodnią byłaby chyba podstawowa materia twórczości poetyckiej, czyli język..11

Język, oczywiście, Wata interesuje, częściej jednak niż język poezji zajmują go mechanizmy dotyczące semantyki języka zideologizowanego, zwłaszcza stalinowskiego. To poszukiwaniu odpowiedzi na pytanie o źródła i istotę komunizmu podporządkowane są wielojęzyczne wypisy z różnych autorów, fragmenty własnych tekstów, układane spisy książek, które koniecznie trzeba przeczytać. Ich rozpiętość jest imponująca i obezwładniająca zarazem.

To, co otrzymujemy w jednym tomie Notatników (ponad 900 stron!), stanowi zbiór heterogeniczny i tak wewnętrznie zróżnicowany, że zrazu czytelnik oszołomiony tym ogromem i kalejdoskopową różnorodnością może odnieść wrażenie, że niepodobna podjąć próby sensownego uspójnienia czy uporządkowania całości. Jednak dwukrotna lektura kilka zasadniczych kwestii pozwala wydobyć.

Na kilkaset stron zapisów Wata składa się łącznie 17 różnej objętości zeszytów. Kwestia ich datowania, o czym mowa we wstępie, nie jest do końca jasna i może być jedynie przybliżona. Dwa pierwsze, oznaczone cyframi rzymskimi (I, II), pochodzą z końca lat 50., czternaście kolejnych (cyfry arabskie, od 1 do 14) z lat 6o., gdy Watowie przebywali już za granicą. Przy okazji warto zauważyć, że taką numerację zaproponowali edytorzy; sam autor bardzo różnie oznaczał swe zeszyty - raz zapisywał na okładce konkretną liczbę (odmienną jednak od tej przyjętej w edycji), innym razem zamieszczał informację o zawartości brulionu (np. na notatniku oznaczonym przez wydawców nr 5 widnieje napis: „Do sprawdzenia / Bibliografia / II / Lektury"). Oczywiście jakiś porządek trzeba było zaproponować, zwracam na to uwagę jedynie, aby przypomnieć, że kolejność części notatników nie oddaje chronologii ich powstawania, o czym, mimo informacji Adama Dziadka,

11 J. Zieliński Kłącza - (kłonice)-synapsy (posłowie), w: A. Wat Notatniki, s. 900. 
łatwo zapomnieć, zwłaszcza że dwa pierwsze i ostatni z brulionów tworzą wyrazistą klamrę temporalną. Notatki w Ostatnim zeszycie (nienumerowanym przez edytorów, a nazwanym tak przez Wata) powstawały u kresu życia pisarza.

Dwa notatniki (I, II) otwierające całość różnią się zdecydowanie od pozostałych. Duża część zapisów w nich pomieszczonych ma formę czytelną i niemal skończoną. To teksty krótsze i dłuższe, często przypominające te, z których ułożony został Dziennik bez samogłosek (niektóre wprost stanowią warianty utworów tam publikowanych, np. Na cmentarzu). Są wśród nich opowiadania, opowiastki, anegdoty, szkice i uwagi o pisarzach (Gałczyńskim, Iwaszkiewiczu, Parandowskim). Większość zapisów to teksty planowane przez Wata do tomu opowiadań Król Lear z Defy, który miał się ukazać nakładem „Czytelnika", zapewne na początku 1960 roku. Na przedostatniej stronie Notatnika II znajduje się nawet dokładny spis treści z autorskimi adnotacjami dotyczącymi rozmiaru kolejnych utworów („kr[ótkie], śr[ednie], dł[ugie]”), a także ich tematyki bądź gatunkowego kształtu. Zaskakiwać może fakt, że pośród tak wielu różnorodnych tekstów o charakterze prozatorskim znajdują się jedynie dwie wzmianki dotyczące poezji; pierwsza to notatki do wiersza Nieszpory w Notre-Dame, druga - przeredagowana wersja młodzieńczego wiersza Staruszkowie, drukowanego ongiś w futurystycznej jednodniówce "Gga" ( $n b$. to ciekawe, dlaczego pisarz po latach wraca do tego niezbyt, zdawać by się mogło, ważnego tekstu - oto jedno z pytań, jakie stawia lektura Notatników). Zapisy z lat 50. uświadamiają, że całą twórczą energię Wat poświęcał wówczas pisaniu prozy, nie poezji. Może dlatego, że tom Wiersze (1957) niedawno się ukazał? Może w innych (zaginionych? niepublikowanych?) notesach pracował nad tekstami poetyckimi? A może postrzegał wtedy siebie przede wszystkim jako prozaika ${ }^{12}$, który publikując tom opowiadań, będący swoistą kontynuacją Bezrobotnego Lucyfera $\mathrm{z}$ dwudziestolecia, umocniłby własną pozycję w ówczesnym świecie literackim?

Wat-prozaik, choć już nie jako twórca form fikcjonalnych, lecz przede wszystkim jako eseista, analityk, historiozof, myśliciel, jest autorem większej części zapisów z notatników oznaczonych numerami od 1 do 14. Monumentalny jest zakres wielojęzycznych lektur, które planował i których spisy ciągną się całymi stronicami; podobne wrażenie robią długie fragmenty wypisów z czytanych artykułów i książek. Towarzyszą im często skrótowe komentarze

12 Zob. P. Pietrych Aleksander Wat w Polsce powojennej (1946-1953). Teksty i konteksty, Wydawnictwo Uniwersytetu Jana Kochanowskiego, Kielce 2011, s. 323-333. 
do tych rozległych lektur, obejmujących oprócz notatek prasowych sprawozdania ze zjazdów partii, pisma filozofów, teologów, pisarzy, antropologów, biologów. Można odnieść wrażenie, że do napisania swej Księgi Wat postanowił przeczytać wszystko. I wszystko przemyśleć w związku z nieustannie planowaną Wielką Syntezą. Właściwie każda z podejmowanych przez Wata lektur i każdy jego tekst domagają się osobnego namysłu, na co zapewne niebawem przyjdzie czas, i zadanie to podejmą kolejni watolodzy. Ja chciałabym tutaj zasygnalizować jedynie, tytułem wyliczenia, kilka kwestii moim zdaniem najważniejszych.

Po pierwsze, niezwykle interesujące notatki (prze-tekst) do eseju Czytając Terca, opublikowanego pod pseudonimem Bergholz jako przedmowa do Opowieści fantastycznych Abrama Terca (pseudonim Andrzeja Sieniawskiego), wydanych przez Instytut Literacki w 1961 roku. Po drugie, przejmujące zapisy doświadczenia bólu pod datą 29/8 62 w ujawniającym się związku z korespondencją Krasińskiego („Ból to nic, ale nicestwo i niemoc to piekło!"). Po trzecie, porozsiewane w różnych miejscach refleksje na temat języka funkcjonującego w przestrzeni zideologizowanej (dlaczego „poezja stała się niemożliwa”) oraz metaliterackie dociekania na temat tego, co znaczy „sens poétique" słowa. Po czwarte, pojawiające się gdzieniegdzie osobiste informacje dotyczące stanu finansów, niespodziewanie zapisana na stronie nazwa leku Octométine czy plan drogi do teatru - to ślady przywołujące widmową obecność autora w jego przestrzeni intymnej. I po piąte, leitmotywicznie powracający temat niemożności zaaprobowania ostatecznego kształtu własnej wypowiedzi:

Gdy więc po odejściu od napisanego / na dystans czytałem oczyma obcego uderzała mnie ta / rozpaczliwa nieprawdziwość, brutalność, a przede wszystkim / opaczność tekstu napisanego. Ja to inaczej nie /doznawałem pisząc, zupełnie inaczej. Pisałem zatem / zawsze napomknienia. ${ }^{13}$

To, co łączy wszystkie notatniki (poza ostatnim, ale nim zajmę się osobno) jest stała właściwość myślenia Wata, ujawniająca się wielokrotnie i na różne sposoby - nieustanne poszukiwanie i konstruowanie analogii. To była jego metoda na odnajdywanie ukrytego porządku w świecie, co do istnienia którego nie miał wątpliwości, który ciągle tropił, próbując go odsłonić czy do niego dotrzeć. Dlaczego Wat tak uporczywie szukał podobieństw między

A. Wat Notatniki, s. 283. 
zjawiskami odległymi w czasie i nieraz bardzo odmiennymi? Sam ujawniał terapeutyczny sens potrzeby odkrywania powinowactw:

budzi się we mnie i od razu potężnieje poczucie du déjà vu, du déjà vécu. A tylko ono, ono jedno, daje mi poczucie, że naprawdę żyję, ja, którego życie od lat jedenastu jest bezładnym falowaniem do śmierci i od niej, tylko to jedno daje mi poczucie bezpieczeństwa, kiedy nowa sytuacja życiowa, przygodna konfiguracja rzeczy, osób, słów, gestów rozpoznaje siebie w identycznych obrazach i równaniach tego, co już było. Tego, tylko tego mi trzeba [...]: wiedzieć, dotknąć, odczuć, że to, co jest, już było, że to, co w tej chwili przeżywam, było już przeżyte i przeżywane, że zatem jest w mocy ludzkiej, zatem w mojej mocy t o przeżyć. [...] Tego, właśnie tego stwierdzenia: du déjà vu, du déjà vecu szukam stale. ${ }^{14}$

Wat miał jednak, co do rezultatów prowadzonego przez siebie śledztwa w sprawie odkrywania w świecie podobieństw, poważne wątpliwości i przestrzegał (również samego siebie) przed nazbyt łatwymi utożsamieniami: „przy pewnej / zręczności można w ten sposób wszystko utożsamić / z wszystkim; pod drugie .odrywając szt[ucznie] jakiś wycinek / z kontekstu, fałszuje się go, odbiera mu się jego moc jedynej świadek[twa] dowodu praw$\mathrm{dy}^{\prime \prime 15}$. Nie zmienia to jednak faktu, że nieustannie chciał rozmaite analogie odkrywać. Stąd również brała się jego skłonność do tworzenia konstrukcji przypowieściowych, quasi-powiastek filozoficznych, manifestująca się, co warto zauważyć, już w opowiadaniach z Bezrobotnego Lucyfera. W Notatnikach najwięcej takich form parabolicznych znajdziemy w zapiskach z końca lat 50. (I i II).

Rewersem predyspozycji do wskazywania podobieństw jest widoczne w notatnikach dążenie przeciwnie - do wydobywania odmienności i niuansów, sam Wat określał to potrzebą distinguo. Wymóg krytycznego rozróżniania, klarownego ujmowania rozpatrywanych problemów, prowadzący do wnikliwych, subtelnych i rozległych (wielostronicowych) analiz danego zjawiska. Z jednej strony te drobiazgowe opisy kolejnych zjawisk czy faktów ratują Wata przed nazbyt zwodniczymi parabolami, z drugiej jednak uniemożliwiają proces scalania i budowania analogii. Ujawnia się w tych zapisach fundamentalna sprzeczność będąca jedną z charakterystycznych cech dzieła 
Wata - potrzeba wszechogarniającej, scalającej pokawałkowane doświadczenie syntezy kontra dążenie do drobiazgowych, erudycyjnych, dygresyjnych, wielowątkowych analiz. Antynomiczność wyznacza ukryty, głęboki nurt tej twórczości.

Lektura Ostatniego zeszytu, który Adam Dziadek słusznie nazywa ,tekstem wyjątkowo wstrząsającym"16, jest przejmującym doświadczeniem. Czytając zapisy tam pomieszczone, mamy świadomość, że to, co znajduje się w jasnobrązowym notesie firmy Rhodia, pisane było jako słowo ostatnie. Znajdują się tu oprócz osobistych, wręcz intymnych listów skierowanych do rodziny, dramatycznych próśb („Na miłość Boską. Tylko nie ratować!”), dyspozycji dotyczących nagrań, które złożyły się potem na Mój wiek, oraz kategorycznych nakazów („Wszystkie papiery nie do wykorzystania” - „najlepiej spalić”) także rękopisy tekstów literackich. Fascynująca jest lektura trzech wersji Wiersza ostatniego i Naszeptów magnetofonowych umożliwiająca śledzenie procesu twórczego, dynamiki zmian, powtórzeń i skreśleń. Po raz pierwszy obcujemy także z takim kształtem brulionu Cośniecoś o Piecyku, który w wersji notatnikowej ma charakter o wiele bardziej złożony, meandryczno-dygresyjny, bowiem oprócz fragmentów odnoszących się bezpośrednio do młodzieńczego poematu zawiera również wiele nawiązań zarówno do biografii, jak i całej twórczości. Dzieje się tak, jakby pisanie o początkach własnej drogi stawało się u kresu dygresyjnym namysłem nad niejasnymi kolejami własnego życia i tworzenia, ujawniającym przy okazji oralny charakter nie tylko tej wypowiedzi Wata. Dokonywany u schyłku bilans przyjmuje, w świetle całych Notatników, formę znaczącego rozliczenia z niezrealizowanych planów. Rozrachunek ze zbyt szczupłego, zdaniem samego Wata, dorobku ujęty w nawias kwadratowy i zaczynający się od słów: „Niech nikt nie posądza mnie o próżność!”17 zawiera wieloaspektową diagnozę własnej „improductivte slave" ${ }^{\text {"18 }}$. Pośród różnych objaśnień znajdujemy również takie: „Mam / taki skład umysłu, że na każdy mój argument / znajduję od razu natychmiast kilka równie ważkich kontrargumentów"'19, wskazujące zasadniczą cechę umysłowości Wata, która uniemożliwiała mu to, do czego przez całe życie zmierzał, napisanie Wielkiej Syntezy.

\footnotetext{
16 A. Dziadek Notatniki Aleksandra Wata z Beinecke Library (Wstęp), w: A. Wat Notatniki, s. 12.

17 A. Wat Notatniki, s. 814.

18 Tamże, s. 817. 
Przejmujące jest w Ostatnim zeszycie zderzenie podjętej przez Wata próby domknięcia własnego życia w formie résumé z ostatnimi, dramatycznymi słowami skierowanymi do najbliższych, tekstami zapisanymi na strzępach wyrwanych kartek, informacji dotyczącymi opłat za komorne czy ledwie widocznymi u dołu stronicy liczbami, poświadczającymi towarzyszącą Watowi do końca potrzebę uporania się z rachunkami. Ta przedśmiertna buchalteria, widok niewyraźnie zapisanych liczb, stanowi dla mnie przejmujący ślad osoby.

Edycja Notatników Wata, dokonana przez Adama Dziadka i Jana Zielińskiego, jest dla watologów rzeczą bezcenną, bowiem przywraca teksty skazane dotąd na całkowite bądź częściowe nieistnienie. Każdy, kto kiedykolwiek zetknął się z trudnym, czasami wydaje się, że niemal niemożliwym do odczytania pismem autora Ciemnego świecidła, nie ma wątpliwości, jakich detektywistycznych umiejętności połączonych z benedyktyńską pracowitością wymaga transliteracja jego zapisów. Nie do przecenienia więc jest pod tym względem zasługa wydawców. Zasługa tym większa, że Notatników nie można potraktować po prostu jako brudnopisów tekstów opublikowanych lub zaniechanych, jako twórczego zaplecza stanowiącego jedynie przygotowanie dla utworów autoryzowanych. Jak już pisałam, status wielu tekstów Wata jest jedynie hipotetyczny i na zawsze nieostateczny. Zapominamy o tym, nawet jeśli informacje o ich rekonstruowanym i jedynie domniemanym kształcie znajdują się w nocie edytorskiej, ponieważ w czytelniczym odbiorze utrwaliła się ich pozycja jako utworów o ustalonej i zamkniętej strukturze. Zapiski umieszczone w siedemnastu zeszytach niedefinitywny i nieostateczny byt tekstowy ujawniają i demonstrują, destabilizując nasze czytelnicze nawyki, domagając się ponownej lektury tekstów tak kanonicznych jak Mój wiek, Coś niecoś o Piecyku czy Dziennik bez samogłosek.

Notatniki można potraktować jako całościową figurę twórczości Wata, ponieważ - jak słusznie zauważa Dziadek

charakter zapisu w notatnikach poety ma bezpośredni związek z całością jego dzieła. Są to z reguły notatki ułożone nielinearnie, wiele z nich zawiera kilka wersji tekstowych. Liczne zmiany, przekreślenia, podkreślenia, zakreślenia na marginesie (nieraz kilkakrotne), poprawki, dopiski na marginesach, przypisy. Stronice notatników jawią się wskutek tego jako pages performatives - do pisania i/lub czytania. Sposób sporządzania notatek oddaje doskonale sposób myślenia i działań twórczych poety. ${ }^{20}$ 
Notatniki uświadamiają zatem dobitnie, że w taki właśnie sposób Wat pisał niemal wszystkie swoje teksty.

Edytorzy sytuują swe przedsięwzięcie w obszarze krytyki genetycznej, której obca jest, jak pisze jeden z twórców tej dziedziny, Pierre-Marc de Biasi, „idea tekstu ustalonego i utrwalonego w niezmiennym kształcie”21 i która kwestionuje pojmowanie dzieła literackiego jako systemu zamkniętego, a tekstualizacji jako sekwencji działań teleologicznie zorientowanych. W to miejsce proponuje wnikliwą analizę samego toku pisania, zastępując ostateczną strukturę dzieła „rozgałęzioną złożonością procesów pisania"22. Notatniki Wata wydają się wręcz idealnym obiektem do tego typu postępowania, bowiem są tekstem, w którym "pisanie [jawi się] jako technika i jako hybris, jako nieumiarkowanie i żądza zmian"23. Potrzeba dokonywania nieustannych przekształceń jest wszakże konstytutywną cechą watowskiej dyspozycji twórczej. Działania Wata układają się w ciąg falstartów ${ }^{24}$, jeśli patrzeć z perspektywy pożądanego finału; jeśli zaś nie poddajemy tekstu presji wyczekiwania „szczęśliwego zakończenia”, wówczas odzyskujemy niczym nieograniczoną dynamikę écriture, bez atycypacji ostatecznego rezultatu ${ }^{25}$.

Z perspektywy nie tylko krytyki genetycznej, ale przed wszystkim badań nad twórczością autora Ciemnego świecidła, niniejsza edycja ma jedną bardzo poważną wadę - nie zawiera reprodukcji rękopisów, które dla rekonstrukcji procesu pisania mają wartość fundamentalną. Choćby najwierniejsza i najrzetelniejsza transliteracja nie może oddać kształtu stronic zapisanych ręką autora - sposobu rozmieszczenia tekstu, wielkości liter, siły nacisku pióra na papier, dynamiki skreśleń czy formy pojawiających się rysunków. To rękopis poświadcza w sposób najpełniejszy osobisty tok pisma i uruchamia

21

M.P. de Biasi Genetyka tekstów, s.48

Tamże, s. 12.

Tamże, s. 49 .

„To, że pisarz postanowił ułożyć plan, jeszcze nie oznacza, że rzeczywiście zaczął pisanie dzieła. W grę może wchodzić «falstart»", tamże, s. 63.

Na marginesie warto zaznaczyć, że presji finalności ulega nawet deklarujący swój akces do krytyki genetycznej edytor, gdyż traktuje on szkicowany przez Wata plan bliżej nieokreślonego utworu jako świadectwo „zadziwiającej j fascynującej przemiany tekstu prozatorskiego w poemat" (s. 11), z jaką mamy jego zdaniem do czynienia, gdy weźmiemy pod uwagę notatki odnoszące się do Wierszy śródziemnomorskich. Sprawa nie jest tak oczywista, same zapisy bowiem nie są wystarczającą przesłanką do tego, aby z pewnością móc stwierdzić, co w tamtym momencie Wat planował napisać - utwór poetycki czy prozatorski, wszakże prawdopodobna jest sytuacja, że notował „prozą", planując od razu napisanie poematu. 
szczególną semantykę, uwzględniającą wszystkie elementy dynamicznego procesu, który przekształcony w ciąg zadrukowanych stronic nieruchomieje i zastyga. Jak ważna to kwestia, uświadamiają dobitnie np. skany Wiersza ostatniego, ponieważ tylko rękopis zawiera takie elementy, które druk ze swej istoty musi poddać unifikacji (choćby wielkość liter czy usytuowanie kolejnych wersji wiersza w stosunku do siebie). Niezrozumiała jest dla mnie decyzja edytorów, aby edycję pozbawić dynamiki materialnego zapisu, a tym samym znacznie ograniczyć pole potencjalnych znaczeń, jakie otwierają notatniki Wata. Krótkie informacje o architektonice rękopisu czynione zgodnie z zasadami edycji niewiele tu zmieniają. Niezrozumiała to decyzja tym bardziej że sami edytorzy przywiązują dużą wagę do takiego sposobu wydania, który uwierzytelnia „naoczne przekazanie procesu formowania tekstu”26, uznają również „somatyczne doświadczenie archiwum”27 za kwestię fundamentalną w trakcie pracy nad niniejszym wydaniem. Oczywiście zdaję sobie sprawę z tego, że żadna edycja nie jest w stanie oddać doznań, jakie pojawiają się podczas bezpośredniego kontaktu z brulionami pisarza - nic nie zstąpi dotyku kartek, szelestu odwracanych stronic, zapachu papieru, a tym bardziej uczucia wzruszenia, jakie tym wrażeniom towarzyszy. To jednak, co można ocalić, to właśnie rękopiśmienny kształt zapisów. Edytorzy, co prawda, reprodukują kilkadziesiąt skanów, ale jest to ilość znikoma w stosunku do tak obszernej całości. Domyślam się, że ich decyzja wynikała z konieczności ograniczenia objętości i tak już wyjątkowo okazałego tomu. Jednak zadaniu reprodukcji rękopisów z łatwością podołałoby wydanie cyfrowe. Trudność wynikającą ze zbyt dużego rozmiaru publikacji książkowej można przekroczyć, odchodząc od tradycyjnej, papierowej formy edycji. Jak słusznie zauważa de Biasi: „W istocie tylko technologie cyfrowe są w stanie rozwiązać problemy, jakie niemal zawsze wynikają z ilości i różnorodności śladów pozostawionych na papierze, a droga ta jest tym bardziej racjonalna, że dzisiejsze «rękopisy» z natury stają się cyfrowe"28. Pozostaje mieć nadzieję, że edytorzy notatników Wata - dysponujący takimi „rękopisami cyfrowymi”, czyli skanami o wysokiej rozdzielczości, pozwalającymi na wnikliwe studia nad spuścizną - niebawem je, przy wykorzystaniu technik informatycznych, udostępnią.

\footnotetext{
26 A. Dziadek Notatniki Aleksandra Wata..., s. 13.

27 Tamże, s. 9, 14-15.

28 M.-P. de Biasi Genetyka tekstów, s. 115.
} 
Drugi istotny mankament to brak rzeczowej i wyczerpującej informacji na temat miejsca, jakie zajmują stanowiące przedmiot niniejszej edycji notatniki w całej spuściźnie Wata znajdującej się w Beinecke Library. Dowiadujemy, że stanowią one "część Aleksander Wat Papers", że zostały „«wyłuskane» z bogatego zbioru archiwalnego", nie wiemy natomiast, czy są to wszystkie zachowane notatniki czy też ich część, na opracowanie której z jakichś względów (jakich?) edytorzy się zdecydowali. Nawet jeśli uważnie przeczytamy opisy archiwum dokonane najpierw przez Ryszarda Zajączkowskiego ${ }^{29}$, potem przez Adama Dziadka ${ }^{30}$, sprawa nie zostanie jednoznacznie rozstrzygnięta. A to przecież kwestia niezwykle istotna.

Nie zmienia to jednak faktu, że obcowanie z zapisami Wata nawet $\mathrm{w}$ tym niedoskonałym kształcie zaproponowanym przez Adama Dziadka i Jana Zielińskiego jest fascynującą lekturą, która przywraca czasowy wymiar tekstu - sprawia, że to, co się niegdyś wydarzyło, ponownie się wydarza. Odzyskujemy w ten sposób dziejący się nieustannie na naszych oczach proces pisania, szkoda że pozbawiony w znacznym stopniu swego fundamentalnego i najbardziej osobistego wymiaru, autografów - depozytariuszy materialności pisma.

W wierszu Przed Breughelem starszym czytamy:

Praca jest dobrodziejstwem.

[...]

Praca jest ratunkiem.

Ja wam to powiadam - ja, Breughel stary (a choćby i t.p.g Wat Aleksander) -

[praca jest ratunkiem".

Notatniki poświadczają, że praca, meandrycznie zapętlona, dramatycznie skupiona na ciągłym rozpoczynaniu od nowa, stale powracająca do tego, co pojawiało się wcześniej już wielokrotnie, praca konstelacyjnie rozgałęziona, wchłaniająca wielość lektur, planów, celów i pomysłów, praca szukającego swego finału, lecz tylko z rzadka go znajdująca - okazała się, bodaj czy

Zob. R. Zajączkowski Warchiwum Aleksandra Wata, „Pamiętnik Literacki” 2007 Z. 1.

A. Dziadek Aleksander Wat w Beinecke Library w Yale, "Teksty Drugie $2009 \mathrm{nr} 6$; w tym artykule znajdujemy jeszcze jedną, choć w interesującej mnie kwestii nic niewyjaśniającą, informację: "Najbardziej intrygującą część zbiorów stanowią notatniki znajdujące się w pudle oznaczonym «Box 8», a to dlatego, że trudno czytelne teksty nie doczekały się dotychczas żadnego opracowania" (s. 256). 
w sposób nie najpełniejszy (co nie znaczy spełniony), drogą realizacji Watowskiego Dzieła nigdy niedobiegającą końca.

\section{Abstract}

\section{Krystyna Pietrych}

UNIVERSITYOF ŁÓDŹ

Notatniki [Notebooks] Instead of the Opus Magnum?

Pietrych reviews Adam Dziadek and Jan Zieliński's transcript and critical edition of Aleksander Wat's Notatniki [Notebooks]. She outlines the tome's content and highlights its key problems. Wat's drafts are conceived of as a trace of the creative process, indicating its changeability, repeated interruption and continuation. Pietrych's reading and evaluation are based on the assumptions of genetic criticism.

\section{Keywords}

Aleksander Wat, draft, creative process, review, genetic criticism 